\title{
LAYANAN RUMAH BELAJAR SEBAGAI MEDIA DALAM PEMBINAAN KREATIVITAS MEMBACA
}

\author{
Studi Kualittaif Studi Kasus Komunitas MAPUSTA JABAR Pada Layanan Rumah Belajar dalam \\ Pembinaan Kreativitas Membaca di Dinas Perpustakaan dan Arsip Daerah (DISPUSIPDA) Jawa
}

Barat

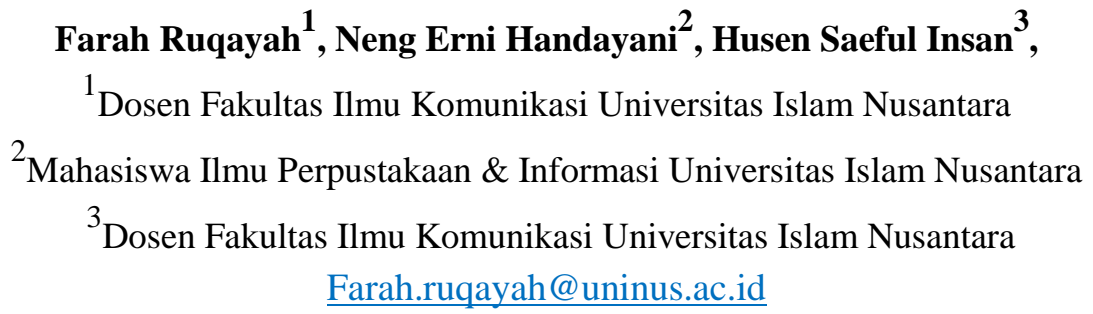

\begin{abstract}
ABSTRAK
Layanan rumah belajar merupakan forum diskusi yang didirikan oleh sebuah komunitas yang di kenal dengan MAPUSTA (Masyarakat Perpustakaan) untuk membatu memberikan kebutuhan informasi bagi masyarakat. Program layanan rumah belajar menjadi salah satu media dalam pembinaan kreativitas membaca bagi peserta didik yang ikut bergabung dalam program tersebut di DISPUSIPDA. Tujuan penelitian untuk mengetahui layanan pada program rumah belajar sebagai media dalam pembinaan kreatifitas membaca. metode penelitian : kualitatif deskriptif dan studi kasus. Informan yang terdapat dalam penelitian ini dibagi menjadi 3 katogori yitu, 1. Peserta didik, 2. Fasilitator, dan 3. Komunitas Masyarakat Perpustakaan (MAPUSTA). Penelitian ini dilaksanakan di Dinas Perpustakaan dan Arsip (DISPUSIPDA) Jawa Barat. Dengan indikator yang terdapat pada penelitian ini seperti fungsi dan peranan program rumah belajar, faktor pendukung pada program rumah belajar, serta prantara sumber belajar yang terdapat pada program layanan rumah belajar. Dari hasil penelitian maka peneliti dapat menyimpulkan bahwa layanan pada program rumah belajar merupakan salah satu media dalam pembinaan kreatifitas membaca bagi peserta didik
\end{abstract}

Kata kunci : layanan rumah belajar, komunitas MAPUSTA, kreatifitas membaca

\section{ABSTRACT}

Home learning services are a discussion forum founded by a community known as MAPUSTA (Library Society) to help provide information needs for the community. The home learning service program is one of the media in developing reading creativity for students who join the program at DISPUSIPDA. The purpose of the study was to find out the services in the learning home program as a medium in developing reading creativity. Research methods: descriptive qualitative and case studies. The informants in this study divided into three categories, 1. Students, 2. Facilitators, and 
3. Community Library Community (MAPUSTA). This research was carried out at the West Java Library and Archives (DISPUSIPDA) Office. With the indicators contained in this study such as the function and role of home learning programs, supporting factors in the learning home program, and learning resources among the learning home service programs. From the results of the study, the researcher can conclude that services in the home learning program are one of the media in the development of reading creativity for students

Keywords: Home learning service, MAPUSTA Community, reading creativity

\section{PENDAHULUAN}

Salah satu lembaga pemerintah yang sesungguhnya amat strategis dalam mendukung proyek peningkatan sumber daya manusia di indoneisa adalah perpustakaan. Namun, di balik premis ini muncul serangkaian pernyataan mengenai lembaga perpustakaan yang hingga saat ini sudah bersikap adaptif atau masih terasa kaku terhadap kebutuhan informasi dan perkembangan zaman, dan sebarapa jauh masyarakat yang sudah merasakan manfaat dari perpustakaan itu sendiri. Dari pernyataan tersebut dapat menjadi salah satu indikator bagi kuat atau lemahnya keseriusan lembaga perpustakaan dalam upaya ikut serta dalam mencerdaskan anak bangsa.

Namun demikian, perpustakaan bukanlah lembaga super yang sanggup mencetak manusia-manusia cerdas dengan sakali jadi. Perpustakaan hanya tempat penyedia barang berupa buku-buku dan referensi atau ilmu pengetahuan lainnya.
Pada akhinya, kesadaran masyarakatlah yang akan menjadi faktor dominan yang menentukan dirasakan atau tidaknya peran perpustakaan. Sebagian masyarakat, menyatakan bahwa perpustakaan merupakan bagian dari kebutuhan yang harus dipenuhi di dalam kehidupan terutama peserta didik atau pelajar, mahasiswa, masyarakat umum dan kelompok-kelompok tertentu untuk menunjang aktivitasnya.

Dengan kata lain perpustakaan sudah memasyarakat, namun dirasakan bahwa sebagian masyarakat yang lain belum mendapatkan fasilitas dan layanan perpustakaan sebagaimana mestinya. Hal ini yang menjadikan sebuah motivasi untuk segera membenahi, dan mengembangkan perpustakaan agar dapat memenuhi tugas dan fungsinya sebagai salah satu pusat informasi, ilmu pengetahuan, teknologi dan budaya, dalam rangka meningkatkan kecerdasan bangsa, meliputi kecerdasan spiritual, 
intelektual, profesional, dan kecerdasan sosial.

Rumah belajar adalah suatu inovasi dari sistem layanan yang berkembang menjadi sebuah program di perpustakaan. Layanan rumah belajar merupakan forum diskusi yang didirikan oleh sebuah komunitas yang di kenal dengan MAPUSTA (Masyarakat Perpustakaan) untuk membatu memberikan kebutuhan informasi bagi masyarakat. Pada mulanya program ini hanya dikhususkan bagi pelajar dan mahasiswa, karna pada dasarnya merekalah yang menjadi acuan utama diadakannya program ini. Tetapi seiring berkembangnya waktu program ini menjadi suatu program yang dibuka untuk umum tanpa adanya terkecuali. Layanan rumah belajar juga menjadi salah satu pusat sumber belajar yang ada di perpustakaan. Berdasarkan Batasan masalah yang diuraikan di atas, maka rumusan masalah, adalah bagaimana layanan rumah belajar sebagai media dalam pembinaan kreativitas membaca di Dinas Perpustakaan dan Kearsipan Daerah (DISPUSIPDA) Jawa Barat.

\section{KAJIAN TEORI}

\section{Membaca}

Dalam pandangan Islam "membaca" merupakan suatu perintah atau sebuah kewajiban bagi umat manusia. Berdasarkan wahyu pertama yang diturunkan oleh Allah SWT kepada Nabi Muhammad Saw, Ayat pertama diturunkan melalui malaikat Jibril sewaktu Nabi Muhammad Saw berada di gua Hira. Hal ini tertera dalam surah ke 96 - AlAlaq (segumpal darah) ayat 1 sampai 5 yang isi dari terjemahannya sebagai berikut:

"Bacalah dengan menyebut nama Tuhanmu Yang menciptakan. Dia telah menciptakan manusia dari segumpal darah. Bacalah dan Tuhanmulah Yang Maha Pemurah. Yang mengajarkan (manusia) dengan perantaraan kalam (baca tulis) Dia mengajarkan manusia apa yang tidak diketahuinya". Sabaruddin Tain (2006) dalam Elfisa, (2012:208).

Pada surah tersebut dijelaskan bahwa manusia pada dasarnya memiliki rasa ingin tahu yang tinggi. Manusia mempunyai kewajiban dalam membangun peradabannya melalui baca tulis, 'iqra' pada Al-Quran sudah tertera jelas bahwa hal itu yang memerintah manusia agar mau membaca. Perintah tersebut juga merupakan wahyu pertama yang diturunkan kenapa Nabi 
Muhammad Saw, yang dapat dijadikan acuan agar manusia mengerti pentingnya membaca.

Membaca termasuk ke dalam unsur terpenting dalam kehidupan manusia. Adapun suatu kepercayaan ataupun agama yang menjelaskan bahwa membaca merupakan suatu momok penting dalam menjalani kehidupan. Setiap individu pada dasarnya harus memiliki kecapakan membaca yang berfungsi sebagai penyerapan informasi dan dapat membantu mengatasi permasalah hidup yang dihadapi agar individu tersebut menjadi seorang manusia yang berbudaya baca (reading society) dan berbasis ilmu pengetahuan (knowledge based society).

\subsection{Tujuan Membaca}

Setiap pembaca memiliki tujuan yang berbeda-beda. Penentuan tujuan tersebut didasarkan pada kebutuhan individu masingmasing. Berdasarkan Tujuan umum menurut Darmono (2001) dalam Suharmono, 2015:83, membaca adalah untuk mendapatkan informasi baru. Tetapi dalam kenyataannya terdapat tujuan yang lebih khusus dari kegiatan membaca, yaitu:

1. Membaca untuk tujuan kesenangan. Termasuk dalam kategori ini adalah membaca novel, surat kabar, majalah, dan komik. Menurut David Eskey tujuan membaca adalah reading for pleasure. Bacaan yang dijadikan obyek kesenangan menurut David adalah sebagai "bacaan ringan".

2. Membaca untuk meningkatkan pengetahuan seperti pada membaca buku-buku pelajaran buku ilmu pengetahuan. Kegiatan membaca untuk meningkatkan pengetahuan disebut juga dengan reading for intelectual profit.

3. Membaca untuk melakukan suatu pekerjaan, misalnya para mekanik perlu membaca buku petunjuk, ibuibu membaca booklet tentang resep makanan, membaca prosedur kerja dari pekerjaan tertentu. Kegiatan membaca semacam ini dinamakan dengan reading for work.

Hasil yang diperoleh dari kegemaran membaca dapat dirasakan langsung oleh diri sendiri. Dengan proses membaca tentu saja penambahan sejumlah pengetahuan semakin meningkat. Ketika membaca buku walaupun tidak dihafalkan tetapi akan teserap langsung di pikiran karna biasanya membaca buku akan ada sebuah imajinasi yang muncul dalam ingatan.

\subsection{Manfaat Membaca}

Membaca merupakan aktivitas yang mempunyai banyak manfaat. Selain menambah wawasan serta informasi, membaca juga bisa bermanfaat bagi otak, kesehatan, dan tubuh manusia bebrapa studi 
percobaan tentang manfaat membaca sudah banyak di uji oleh para ahli tentang hal tersebut.

Manfaat membaca juga merupakan sebuah fondasi dari proses belajar. Membaca untuk kesenangan merupakan jenis aktivitas yang mengarah pada pengembangan keinginan dan minat dari diri sendiri (Krashen, 2004: X, 1). Manfaat lain dari baca itu sendiri adalah bagaimana sebuah pengetahuan dapat di aplikasikan secara langsung dalam kehidupan sehari-hari. Tanpa membaca seseorang tidak akan mengerti bagaimana proses sebuah pembelajaran dapat berlangsung dengan adanya informasi.

\subsection{Faktor-Faktor dalam Membaca}

Menurut Pandawa, dkk (2009) dalam Arisma, 2012 :29 ada beberapa faktor yang berpengaruh terhadap proses pemahaman dalam membaca, yaitu sebagai berikut:

1) faktor kognitif,

2) faktor afektif,

3) faktor teks bacaan,dan

4) faktor penguasaan bahasa.

Faktor yang pertama berkaitan dengan pengetahuan, pengalaman, dan tingkat kecerdasan (kemampuan berpikir) seseorang. Faktor kedua berkaitan dengan kondisi emosional, sikap, dan situasi. Faktor ketiga berkaitan dengan tingkat kesukaran dan keterbacaan suatu bacaan yang dipengaruhi oleh pilihan kata, struktur, isi bacaan, dan penggunaan bahasanya. Selanjutnya faktor terakhir berkaitan dengan tingkat kemampuan berbahasa yang

berkaitan dengan penguasaan perbendaharaan kata, struktur, dan unsurunsur kewacanaan.

\section{Kreativitas}

Karakter yang paling penting dan dianggap lebih bernilai dari individu yaitu suatu kreativitas. Kreativitas merupakan kemampuan yang dimiliki oleh semua orang (dalam derajat tertentu), bahkan juga merupakan suatu keterampilan yang dapat dikembangkan secara penuh. Seperti kemampuan kreativitas dalam mengatasi masalah atau kemampuan memberikan ideide baru dan menjalankan pemikirinpemikiran dalam sebuah pekerjaannya.

Seperti menurut Suryana (2003) dalam Hadiyani 2011 :10, menyatakan bahwa kreativitas adalah:

"Berpikir sesuatu yang baru". "Kreativitas sebagai kemampuan untuk mengembangkan ide-ide baru dan untuk menemukan cara-cara baru 
dalam memecahkan persoalan dalam menghadapi peluang". Kreativitas merupakan suatu topik yang relevan tidak hanya bagi wirausaha yang baru memulai, tetapi juga bagi bisnis dan kegiatan bisnis pada umumnya.

Kreativitas juga merupakan sebuah inisiatif terhadap suatu yang dapat di katakana sebagai produk atau proses yang bermanfaat, benar, tepat, dan bernilai terhadap suatu tugas yang lebih bersifat heuristic yaitu sesuatu yang merupakan pedoman, petunjuk, atau panduan yang tidak lengkap yang akan menuntun untuk mengerti, mempelajari, atau menemukan sesuatu yang baru.

\section{Media}

Media telah mempengaruhi seluruh aspek kehidupan manusia, meskipun dalam derajat yang berbeda-beda. Di negaranegara maju media telah mempengaruhi kehidupan hampir sepanjang waktunya, dengan kata lain lebih banyak ekspos media dari waktu yang dipergunakan untuk tidur, dan juga berarti lebih banyak dari waktu yang digunakan untuk belajar.

Penggunaan media dalam pengajaran di kelas merupakan sebuah kebutuhan yang tidak dapat diabaikan. Hal ini dapat dipahami mengingat proses belajar yang dialami siswa tertumpu pada berbagai kegiatan menambah ilmu dan wawasan untuk bekal hidup di masa sekarang dan masa akan datang.

Tabrani Rusyan dan Yani Daryani (1993) dalam Umar, 2013:127 menjelaskan, salah satu upaya yang harus ditempuh adalah bagaimana menciptakan situasi belajar yang memungkinkan terjadinya proses pengalaman belajar pada diri siswa dengan menggerakkan segala sumber belajar dan cara belajar yang efektif dan efisien.

\section{Layanan Perpustakaan}

Layanan dalam Kamus Besar Bahasa Indonesia berarti perihal atau cara melayani. Sedangkan, melayani adalah membantu menyiapkan (mengurus) apa-apa yang diperlukan seseorang.

Pelayanan perpustakaan adalah suatu upaya yang dilakukan oleh pustakawan sekolah agar bahan-bahan pustaka dapat dimanfaatkan dan diberdayagunakan dengan optimal oleh para pemakai perpustakaan (atau para pembaca). Sehingga, perpustakan dapat menjalankan seluruh fungsi-fungsinya dengan baik. (Prastowo, 2012 : 243)

Layanan perpustakaan mungkin mengalami perkembangan, oleh karena itu frekuensi kunjung dan pemanfaatan sangatla menentukan agar pemustaka mengetahui 
pasti layanan tersebut dan kualitasnya. Sutarno (2006: 190) menjelaskan mengenai prinsip-prinsip layanan itu seperti, (a) sesuai dengan atau untuk kebutuhan masyarakat yang dilayani, (b) diusahakan berlangsung cepat, tepat, mudah dan sederhana, (c) diciptakan kesan yang menarik dan menyenangkan atau memuaskan pemakai/ penerima layanan.

\section{Sistem Layanan Perpustakaan}

Sistem layanan perpustakaan biasanya ditentukan oleh beberapa hal yaitu jumlah pustakawan, jumlah koleksi yang dimiliki perpustakaan, jumlah pemakai yang dilayani, jenis layanan, macam layanan yang tersedia, dan besar kecilnya gedung perpustakaan. Sistem layanan perpustakaan dapat dibedakan kedalam dua sistem, yakni :

\section{a. Sistem terbuka (open acces)}

Sistem layanan terbuka (open acces), pada sistem ini para pengguna perpustakaan bebas mencari sendiri informasi yang terekam dalam suatu dokumen berupa buku atau non buku (book material atau pun non book material). Keuntungan sistem ini diantaranya pemakai bebas memilih koleksi pustaka yang diinginkan. Pemakai mempunyai peluang alternatif lain dalam memilih koleksi, khususnya ketika ia tidak menemukan apa yang dikendakinya. $b$.

Sistem tertutup (close acces)

sistem layanan tertutup, biasanya pemakai terlebih dahulu mencari daftar koleksi yang diinginkan pada katalog. Keuntungan sistem ini diantaranya koleksi perpustakaan akan tetap terjaga susunannya. Kemungkinan terjadinya kehilangan bahan pustaka relatif sangat kecil. Sedangkan kerugian dari sistem ini diantaranya untuk memilih buku lain tidak bisa bebas. Butuh banyak petugas pelayanan. Butuh banyak waktu untuk melayani peminjaman.

Agar layanan dapat memuaskan orang atau kelompok yang dilayani, maka petugas harus memenuhi 4 karakter pokok yaitu: Pertama adalah tingkah laku yang sopan. Kedua adalah cara penyampaiaan sesuatu yang berkaitan dengan apa yang seharusnya diterima oleh orang yang yang bersangkutan. Ketiga adalah waktu menyampaikan yang tepat. Keempat adalah keramah tamahan.

\section{Teori Uses And Gratifications}

Herbert Blumer dan Elihu Katz adalah orang pertama yang mengenalkan teori ini. Teori uses and gratification 
(kegunaan dan kepuasan) ini dikenalkan pada tahun 1974 (dalam Yuliani, 2017 : 18) dalam bukunya the uses on mass communication : current perspectives on gratification research. Teori uses and gratifications milik blumer dan katz ini berasumsi bahwa pengguna media memainkan peran aktif untuk memilih dan menggunakan media tersebut. dengan kata lain, pengguna media adalah pihak yang aktif dalam proses komunikasi. Pengguna media berusaha untuk mencari sumber media yang paling baik dalam usaha memenuhi kebutuhannya. Artinya, teori uses and gratifications

mengonsumsikan bahwa pengguna mempunyai pilihan alternatif untuk memuaskan kebutuhannya.

Teori uses and gratifications lebih menekankan pada pendekatan manusiawi dalam melihat media massa. Artinya, manusia itu sendiri mempunyai otonomi, wewenang untuk memperlakukan media. Blumer dan Katz (1974) percaya bahwa tidak hanya ada satu jalan lagi khalayak untuk menggunakan media. Sebaliknya, mereka percaya bahwa ada banyak alasan khalayak untuk menggunakan media. Menurut pendapat teori ini, konsumen media mempunyai kebebasan untuk memutuskan bagaimana (lewat media mana) mereka menggunakan media dan bagaimana media itu akan berdampak pada dirinya.

Teori ini juga menjadi salah satu teori yang paling popular tentang komunikasi massa adalah pendekatan penggunaan dan kepuasaan (Uses and gratification). Pendekatan ini berfokus pada konsumenanggota-audiens-ketimbang pada pesannya. Dasar utama dari asumsi ini ialah :

"dibandingkan dengan penelitian pengaruh. Pendekatan penggunaan dan kepuasan berfokus pada konsumen media ketimbang pesan media sebagi titik awalnya, dan menelusuri perilaku komunikasinya dalam artian pengalaman langsungnya dengan media. Jadi, pendekatan ini tidak mengharapkan adanya hubungan langsung antara pesan dan pengaruh, tetapi sebaliknya merumuskan pesanpesan yang akan digunakan oleh audiens, dan bahwa

penggunaan tersebut bertindak sebagai variable pengalang dalam proses pengaruh".

Di sini, di jelaskan bahwa audiens dianggap sebagai audiens aktif dan diarahkan oleh tujuan. Audiens sangat bertanggung jawab dalam memilih media untuk untuk memnuhi kebutuhan mereka sendiri. Dalam pandangan ini, media dianggap sebagai satusatunya faktor yang mendukung bagiamana sebagai perantara yang besar : mereka tahu kebutuhan mereka dan bagaimana memenuhi 
kebutuhan tersebut (Litllejohn, Stephen W, $2011:$ 426).

\section{METODE PENELITIAN}

$$
\text { Metode yang digunakan dalam }
$$
penelitian ini adalah metode penelitian kualitatif deskriptif Peneliti menggunakan metode ini ingin mengetahui tentang layanan rumah belajar yang ada di DISPUSIPDA melalui sebuah komunitas dan keefektifitapan dalam peningkatan kreativitas membaca bagi peserta didik yang ada di layanan tersebut. Ada beberapa teknik dalam pengumpulan data adalah sebagai, yaitu observasi, wawancara dan studi dokumentasi.

\section{PEMBAHASAN}

\section{Fungi Dan Peranan Layanan Rumah}

\section{Belajar Sebagai Media Dalam}

\section{Pembinaan Kreatifitas Membaca}

untuk mengetahui fungsi dan peranan dari program layanan rumah belajar yang ada di DISPUSIPDA JABAR penulis menemukan beberapa point penting dalam pemenuhan kebutuhan informasi. seperti yang sudah di jelaskan dalam hasil wawancara sebelumnya kegiatan ini memang merupakn sebuah forum diskusi yang terbuka dan peserta didiknya boleh dari berbagai kalangan tanpa terkecuali (masyarakat umum). Program ini pun menjadi program tahunana yang banyak diminati oleh masyakarat karna memang program ini menjadi salah satu pemenuhan kebutuhan infromasi bagi masyarakat. Peran dari program ini merupakan sebuah media dimana media tersebut menjadi wadah atau tempat bagi masyarakat yang akan membantu dalam pembinaan kreativitas membacanya.

Kreativitas ini di bantu dengan adanya kegiatan pembelajaran yang menyertakan beberapa mata pelajaran dalam lingkungan yang dibutuhkan. Seperti mata pelajaran bahasa jepang, English for adulf, English for children, tari tradisional, public speaking, kepenulisan, kewirausahaan, photografi, dan gitar klasik. Hal inilah yang mendorong program layanan tersebut menjadi peran penting dalam membantu pembinaan masyarakat dalam kreativitas membaca yang nantinya akan berguna untuk masyarakat itu sendiri.

Dalam temuan hasil wawancara juga menyertakan bahwa apa yang peserta didik pikirkan memang benar adanya dengan kebutuhan mereka dalam pembinaan ini. 
Program yang menajdi salah satu penyelenggaran yang ada di DISPUSIPDA ini menjadi daya tarik sediri bagi pemustaka untuk datang keperpustakaan.

\section{Faktor Pendukung Dalam Layanan Rumah Belajar Sebagai Media Dalam Pembinaan Kreativitas Membaca.}

Dalam keterkaitannya faktor pendukung dalam program layanan rumah belajar menjadi daya tarik bari pemustaka. Dimulai dengan fasilitas yang memadai, fasiltator yang disediakan membuat para peserta betah dalam program pembelajaraan yang ada, hingga media yang biasa digunakan oleh fasilitator itu sendiri ketika pembelajaran sedang berlangsung di dalam kelas. Hal yang penulis amati dalam program layanan rumah belajar ini faktor yang paling terlihat yaitu jelas ialah fasilitas yang diterima oleh pemustaka atau peserta didik. Dengan kursi yang nyaman, tempat yang begitu luas dan program yang menjadi salah satu wadah untuk pemenuhan kebutuhan informasi ini memang sangat cocok bagi masyarakat apalagi bila dilihat dari segi biaya yang di keluarkan untuk program layanan rumah belajar yang ada di DISPUSIPDA JABAR, tidak semahal dengan tempat bimbel lainnya tapi dari segi penambahan ilmu serta diskusi yang di berikan tidak jauh berbeda dengan bimbel-bimbel yang ada di luar sana.

\section{Perantara Sumber Belajar Yang} Terdapat Di Layanan Rumah Belajar Sebagai Media Dalam Pembinaan Kreatifitas Membaca.

Komunitas MAPUSTA merupakan salah satu prantara yang menjalankan program rumah belajar. Hal yang terpenting dalam prantara ini merupakan peprustakaan itu sendiri yaitu DISPUSIPDA JABAR. Karna prantara di sini merupakan sebuah tempat atau wadah dimana para pemustaka dapat mengikuti program layanan rumah belajar, selain itu yang menjadi prantara lain dalam lingkungan program rumah belajar yaitu fasilitator. Karna pada dasarnya fasilitator disinilah yang menjadi sumber informasi bagi perserta didik dalam pembinaan kreativitas membaca.

Sedangkan dalam media yang menjadi bahan acuan dasar bagi para pemustaka untuk membatu dalam proses pembelajaran agar informasi yang diterima menjadi sumber penambahan ilmu pengetahuan bagi masyarakat. Dalam proses wawancara yang telah dilakukan oleh peneliti, peneliti menenemukan beberapa fakta mengenai media yang digunakan. Betul adanya jika pembelajaran yang terjadi dalam 
program layanna rumah belajar ini

menggunakan media yang berupa media cetak yaitu modul dan teknik komunikasi langsung yaitu seperti tanya jawab dalam pembelajaran bahasa jepang dan untuk mata pelajaran bahasa inggris atau English for adulf menggunakan teknik tanya jawab secara langsung tapi terkadang menggunakan media hiburan berupa pemutaran music atau lagu yang hits ketiaka sebelum dan setelah pembelajaran yang dilakukan oleh program layanan rumah belajar itu berjalan.

\section{KESIMPULAN}

Sesuai dengan hasil penelitian dan pembahasan yang telah diuraikan dalam bab sebelumnya, dapat ditarik kesimpulan sebagai berikut:

1. Fungsi dan peranan rumah
belajasebagai media pembinaan kreativitas membaca, sudah berfungsi sebagai mana mestinya pernyataan ini di dukung dengan perolehan hasil data yang telah didapat oleh peneliti bahwa program rumah belajar merupakan salah satu sarana tempat pembinaan kreativitas membaca melalui kegiatan diskusi dan beberapa pelatihan yang dilaksanakan di program rumah belajar tersebut.

2. Faktor pendung dalam program layanan rumah belajar merupakan media yang dapat membantu dalam proses pembelajaran serta seperti asumsi dasar pada penelitian ini yang menyatakan bahwa audiens atau pemustakalah yang memilih media dalam pemenuhan kebutuhannya. Pada teori uses and gratification juga mengatakan bahwa audiens disini bertindak aktif bukan pastif maka dari itu pemilihan media dalam proses pembinaan kreatifitas membaca pada layanan program rumah belajar ini menjadi salah satu faktor pendukung.

3. Komunitas MAPUSTA JABAR merupakan prantara sumber belajar yang ada pada program layanan rumah belajar. Komunitas MAPUSTA merupakan penyelenggara atau panitia pada program tersebut, dengan adanya komunitas ini maka program layanan rumah belajar dapat berjalan sebagai mana mestinya. Dan kegiatan ini juga dilaksanakan di DISPUSIPDA JABAR. 


\section{DAFTAR PUSTAKA}

Elfisa, M.Khaironi, Yunaldi. (2012). Layanan Pustakawan Anak Terhadap Anak di Perpustakaan Proklamator Bung Hatta Dalam Menumbuhkan Minat Baca. Padang: FBS Universitas Negeri Padang

Suharmono, Kasiyun. (2015). Upaya Meningkatkan Minat Baca Sebagai Media Sarana Untuk Mencerdaskan Bangsa. Surabaya: Jurnal Pena Indonesia (JPI).

Hadayati, Ernani. (2011). Kreativitas dan Inovasi Berpengaruh Terhadap Kewirausahaan Usaha Kecil.
Malang: Universitas Gajayana Malang.

Yuliani, Lia. (2017). Strategi Komunikasi Radio Republik Indonesia Bandung Dalam Membangun Kepercayaan Publik. Bandung : Universitas Islam Nusantara.

Arisma, Olynda Ade. (2012). Peningkatan Minat dan Kemampuan Membaca Melalui Penerapan Program Jam Baca Sekolah di Kelas VII SMP Negeri 1 Puri. Malang: Universitas Negeri Malang (S1 Pendidikan Bahasa, Sastra Indonesia dan Daerah.)

Umar. (2013). Media Pendidikan: Peran dan Fungsinya Dalam Pembelajaran. Jurnal Tabawiyah. 